\title{
Distinct Developmental Requirements for Isolated Lymphoid Follicle Formation in the Small and Large Intestine
}

\section{RANKL Is Essential Only in the Small Intestine}

Kathryn A. Knoop, ${ }^{*}$ Betsy R. Butler, ${ }^{*}$ Nachiket Kumar, ${ }^{*}$ Rodney D. Newberry, ${ }^{\dagger}$ and Ifor R. Williams*

From the Department of Pathology and Laboratory Medicine,* Emory University School of Medicine, Atlanta, Georgia; and the Department of Internal Medicine, ${ }^{\dagger}$ Washington University School of Medicine, St. Louis, Missouri

Cryptopatches (CPs) and isolated lymphoid follicles (ILFs) are organized intestinal lymphoid tissues that develop postnatally in mice and include stromal cells expressing the receptor activator of nuclear factor kappa-B ligand (RANKL). We investigated how stromal RANKL influences the development and differentiation of CPs and IIFs by analyzing the development of these lymphoid structures in knockout mice lacking RANKL. We found that

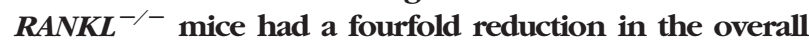
density of CPs in the small intestine compared to control mice, with the largest decrease in the proximal small intestine. No B cells were present in CPs from the small intestine of $R A N K L^{-/-}$mice and IIF formation was completely blocked. In sharp contrast, colonic IIFs containing B cells were present in $R A N K L^{-/-}$mice. Stromal cells within CPs in the small intestine of $R A N K L^{-/-}$mice did not express CXCL13 (originally called B lymphocyte chemoattractant) and often lacked other normally expressed stromal cell antigens, whereas colonic lymphoid aggregates in $R A N K L^{-/-}$mice retained stromal CXCL13 expression. The CXCL13-dependent maturation of precursor CPs into ILFs is differentially regulated in the small intestine and colon, with an absolute requirement for RANKL only in the small intestine. (Am J Pathol 2011, 179:1861-1871; DOI: 10.1016/j.ajpath.2011.06.004)

Lymphoid organogenesis is dependent on a series of complex interactions involving multiple cell adhesion molecules, chemokines, cytokines, and their receptors. ${ }^{1}$
The development of each type of organized lymphoid tissue is characterized by a differential degree of reliance on individual mediators. For example, receptor activator of NF- $\kappa$ B ligand (RANKL) is a tumor necrosis factor (TNF) superfamily cytokine that is essential for the development of some types of lymphoid tissue (eg, lymph nodes), but dispensable for other lymphoid structures such as Peyer's patches (PPs) and thymus. ${ }^{2,3}$ In lymph node development, RANKL has an obligate role in the establishment of the positive feedback loops involving lymphotoxin (LT) $\alpha_{1} \beta_{2}$-producing lymphoid tissue inducer (LTi) cells, and LT $\beta$ R-expressing lymphoid tissue organizer cells. ${ }^{4,5}$

Besides PPs, the gut-associated lymphoid tissue of mice also includes two additional types of smaller organized lymphoid tissues, cryptopatches (CPs) and isolated lymphoid follicles (ILFs). ${ }^{6}$ CPS, the smaller of these lymphoid tissues, are found in the deep lamina propria adjacent to the crypts where they develop postnatally starting on day 14. Under normal homeostatic conditions, there are approximately $1500 \mathrm{CPs}$ in the small intestine and 150 in the colon. ${ }^{6-8}$ An ILF is a single B-cell follicle that develops a germinal center on maturation and can serve as an inductive site for IgA responses. ${ }^{9,10}$ A single ILF fills up an entire villus and is covered by a follicleassociated epithelium (FAE) containing $M$ cells, that is similar to the FAE of PPS. A normal adult mouse has approximately 100 to 200 ILFs in the small intestine and 50 in the colon. ${ }^{9}$ Recently, it has been suggested that CPs and ILFs are not distinct types of intestinal lymphoid

Supported by grants from the National Institutes of Health (DK64730 to I.R.W., and DK64399 supporting the Imaging Core Facility of the Emory Digestive Diseases Research Development Center) and the Crohn's \& Colitis Foundation of America (Senior Research Award to I.R.W.).

Accepted for publication June 3, 2011.

Address reprint requests to Ifor R. Williams, M.D., Ph.D., Department of Pathology and Laboratory Medicine, Emory University School of Medicine, Whitehead Bldg. 105D, 615 Michael St., Atlanta, GA 30322. E-mail: irwilli@emory.edu. 
tissue, but rather two extremes on a continuum of solitary intestinal lymphoid tissue (SILT). ${ }^{11}$ Current evidence suggests that the number of SILT structures in the intestine is normally stable after postnatal development is completed. ${ }^{8}$ Instead, changes to the size and composition of the SILT occur in response to changes in the status of the commensal flora. Although CPs are present in germ-free mice, the development of ILFs in the small intestine from these precursor $\mathrm{CPs}$ requires signals originating with the commensal enteric flora. ${ }^{7,12-14}$

We have previously shown that RANKL is expressed on stromal cells found throughout CPs, but is preferentially expressed by stromal cells located in the subepithelial dome of ILFs and PPs. ${ }^{15}$ We also showed RANKL appears on stromal cells later in ontogeny than other stromal cell antigens including the follicular dendritic cell marker FDC-M1, vascular cell adhesion molecule 1 (VCAM-1), and CD157, and can still be induced when $\mathrm{LT} \alpha_{1} \beta_{2}$ signaling through the $\mathrm{LT} \beta \mathrm{R}$ is blocked. In this study, we used $R A N K L^{-1-}$ mice to further investigate the role of RANKL in the development of CPs and ILFs, and found that in the absence of RANKL small intestinal, but not colonic, CPs fail to express CXCL13, recruit B cells, or develop into ILFs.

\section{Materials and Methods}

\section{Mice}

$R A N K L^{-1-}$ mice on a C57BL/6 background were obtained from a breeding colony maintained in a conventional, specific pathogen-free mouse facility at Emory University. This colony was established with mice provided by Dr. Yongwon Choi at the University of Pennsylvania (Philadelphia, PA). Mice heterozygous for the RANKL null mutation were also backcrossed to BALB/ cByJ mice (The Jackson Laboratory, Bar Harbor, ME) for at least four generations to allow intercrossing of male C57BL/6 RANKL ${ }^{+/-}$mice and female BALB/c RANKL ${ }^{+/-}$ mice, and production of $R A N K L^{-1-}$ mice and littermate controls on a background roughly equivalent to (C57BL) $6 \times \mathrm{BALB} / \mathrm{c}) \mathrm{F} 1$ mice. A higher fraction of $R A N K L^{-1-}$ mice offspring on the $F_{1}$ background survived into adulthood. All experiments using $R A N K L^{-1-}$ mice were done with mice on a C57BL/6 background and/or mice on a $(\mathrm{C} 57 \mathrm{BL} / 6 \times \mathrm{BALB} / \mathrm{c}) \mathrm{F} 1$ background, as indicated in the figure legends. Since equivalent results were obtained with $R A N K^{-1-}$ mice on both backgrounds, the quantitative data were pooled for the figures. All control mice used were littermates to the $R A N K L^{-1-}$ mice, and these controls included both wild-type mice (RANKL ${ }^{+/+}$) and heterozygous mice ( $\left.R A N K L^{+/-}\right)$. Genotyping of mice for the RANKL null mutation was done using a three PCR primer system as previously described. ${ }^{16}$ The mice used were at least 8 weeks old. All animal studies were reviewed and approved by the Emory University Institutional Animal Care and Use Committee.

\section{Antibodies}

The monoclonal antibodies used for immunofluorescence detection of mouse cells on frozen sections included PEand FITC-anti-Thy-1 (53-2.1; eBioscience, San Diego, CA), PE-anti-CD157 (BP-3; eBioscience), biotin-antiVCAM-1 (429; BD Biosciences, San Diego, CA), PE-antiCD11C (HL3; eBioscience), allophycocyanin- and FITCanti-B220 (RA3-6B2; eBioscience), unconjugated FDC-M1 (BD Biosciences), and unconjugated anti-glycoprotein 2 (GP2) (2F11-C3; MBL International, Woburn, MA). Biotinylated antibodies were detected using streptavidin conjugated to Alexa488 or Alexa647 (Invitrogen, Carlsbad, CA). Unconjugated anti-GP2 was detected with Alexa546-conjugated goat anti-rat IgG (Invitrogen). Unconjugated FDC-M1 was detected with biotinylated goat anti-rat IgG (Invitrogen) followed by horseradish peroxidase-conjugated streptavidin and tyramide signal amplification (PerkinElmer, Waltham, MA). CXCL13 was detected with biotinylated polyclonal goat anti-mouse CXCL13 (R\&D Systems, Minneapolis, MN) followed by horseradish peroxidase-conjugated streptavidin and tyramide signal amplification.

\section{Immunofluorescence Staining of Frozen Sections}

The small intestine and colon were excised, placed in cold PBS, and then opened longitudinally. For horizontal sections of the small intestine or colon, three small sheets of tissue (approximately $15 \times 20 \mathrm{~mm}$ ) were stacked and covered with TissueTek optical cutting temperature freezing medium (VWR Scientific, Radnor, PA). Swiss rolls of small intestine or colon were prepared for vertical sections. PPs were excised from surrounding tissue and blocked separately. For anti-GP2 staining, colon tissue was fixed in buffered formalin for 10 minutes before blocking in optical cutting temperature compound. The tissue blocks were quickly frozen in cold 2-methylbutane on dry ice. Frozen sections of 6 - $\mu \mathrm{m}$ thickness were cut with a cryostat, air dried overnight, and fixed for 10 minutes in acetone at $-20^{\circ} \mathrm{C}$. Endogenous peroxidase activity was quenched with $0.3 \% \mathrm{H}_{2} \mathrm{O}_{2}$ in PBS for 30 minutes at $37^{\circ} \mathrm{C}$. Sections were rinsed with PBS and blocked with TNB buffer (PerkinElmer). To obtain optimal staining results when staining intestinal tissues for the soluble chemokine CXCL13, the tissue was fixed in situ by perfusion of mice with $3 \mathrm{~mL}$ of PBS, followed by $5 \mathrm{~mL}$ of $4 \%$ paraformaldehyde and then $3 \mathrm{~mL}$ of $5 \%$ sucrose as previously described. ${ }^{17}$

\section{Quantitative Analysis of CP and ILF Development}

CPs and ILFs in mice were quantitated by counting the number of intestinal lymphoid aggregates on H\&E- or anti-Thy-1-stained sections and using ImageJ software (http://rsb.info.nih.gov/ij) to calculate their density (expressed as aggregates per square centimeter of crypt lamina propria area) and the area of individual aggre- 
gates. In some experiments, the observed lymphoid aggregates were also assigned to one of six classes based on size (Class I: $<5000 \mu \mathrm{m}^{2}$; Class II: 5000 to 10,000 $\mu \mathrm{m}^{2}$; Class III: 10,000 to $15,000 \mu \mathrm{m}^{2}$; Class IV: 15,000 to $20,000 \mu \mathrm{m}^{2}$; Class V: 20,000 to $50,000 \mu \mathrm{m}^{2}$; Class VI: $>50,000 \mu \mathrm{m}^{2}$ ), as previously described. ${ }^{8,14}$

\section{In Utero Treatment of Mice with LT RR-Ig}

To generate mice without PPs that develop increased numbers of intestinal ILFs postnatally, timed pregnant C57BL/6 RANKL ${ }^{+/-}$mice, which had been mated to C57BL/6 RANKL ${ }^{-1-}$ mice, were injected i.v. with purified human $L T \beta R$-lg fusion protein as described previously. ${ }^{15}$ Injections of $100 \mu \mathrm{g}$ of $L T \beta R$-lg were given on embryonic days 14 and 16. The RANKL ${ }^{+/-}$and $R A N K L^{-1-}$ offspring were sacrificed at 8 weeks of age, and tissue from the small intestine was analyzed. In all of the in utero-treated mice, the absence of PPs was verified by gross examination.

\section{Recombinant Mouse RANKL}

A fusion protein of glutathione $S$-transferase (GST) and mouse RANKL (137-316) was generated using a bacterial expression construct as previously described. ${ }^{18}$ The GST-RANKL fusion protein was administered to RANKL null mice by initial i.p. and s.c. injections of $100 \mu \mathrm{g}$ of GST-RANKL followed by s.c. injections of $100 \mu \mathrm{g}$ per day for the next 4 days. Recombinant GST prepared from empty pGEX-5X-1 vector was used as a control for GSTRANKL.

\section{Statistical Analysis}

Differences between the mean values for groups were analyzed by either two-tailed analysis of variance (for multiple groups) or two-tailed Student's $t$-test as calculated using Prism (GraphPad Software, San Diego, CA). A $P$ value of $<0.01$ was considered significant.

\section{Results}

\section{The Small Intestine of RANKL ${ }^{-1-}$ Mice Has a Reduced Density of CPs with Decreased Size}

CPs can be easily identified in sections from the small intestine by staining for Thy-1-expressing LTi cells. The mean density of small CP-sized aggregates in the pericryptal lamina propria of control mice was 19.5 aggregates per $\mathrm{cm}^{2}$, with no difference in density between the jejunum and ileum. In RANKL ${ }^{-1-}$ mice, the overall density of CPs was significantly reduced (Figure $1, \mathrm{~A}$ and $\mathrm{B}$ ) to 4.8 aggregates per $\mathrm{cm}^{2}$. In addition, the density of CPs in RANKL ${ }^{-1-}$ mice was higher in the distal small intestine compared to the proximal small intestine (Figure 1B). CPs from $R A N K L^{-1-}$ mice were also smaller compared to CPs in control mice (Figure 1C). Control small intestinal CPs had a mean area of $21,626 \mu \mathrm{m}^{2}$, whereas CPs in
RANKL ${ }^{-1-}$ mice averaged just $5410 \mu \mathrm{m}^{2}$, or approximately a fourfold decrease.

\section{RANKL $^{-1-}$ Mice Do Not Develop $B$ Cell-Containing ILF}

Surprisingly, all of the small intestinal lymphoid aggregates observed in the RANKL ${ }^{-1-}$ mice lacked $\mathrm{B}$ cells (Figure 2A). Because no small intestinal lymphoid aggregates aside from PPs contained $\mathrm{B}$ cells in $R A N K L^{-1-}$ mice, all non-PP lymphoid aggregates in $R A N K L^{-/-}$mice can be classified as CPs. To further assess the apparent size difference of CPs between control and RANKL ${ }^{-1-}$ mice, a classification system for SILT based on their cross-sectional area originally developed by Pabst et $\mathrm{al}^{14}$ was applied to the analysis of small intestinal lymphoid aggregates from $\mathrm{RANKL}^{-1-}$ and control mice. Both Classes I and II SILTs are typically CPs with few, if any, $\mathrm{B}_{22} \mathrm{O}^{+}$cells. Classes III, IV, and V have progressively larger $\mathrm{B}_{220^{+}}$clusters and can be deemed immature ILFs. Mature ILFs with full-sized B-cell follicles typically fall into the Class VI category. Although the SILT structures in control mice showed the expected degree of diversity and were distributed among all six classes, $80 \%$ of the RANKL ${ }^{-1-}$ aggregates fell into Class I and Class II, consistent with most of these structures being small CPs (Figure 1C). The RANKL ${ }^{-1-}$ aggregates falling into Classes III, IV, and V, which are typically the immature ILF classes, lacked B cells and therefore do not qualify as ILFs. Even the largest lymphoid aggregates in the $R A N K L^{-1-}$ mice that filled up an entire villus contained no $B$ cells (Figure $2 B$ ). The classification of $20 \%$ of the lymphoid aggregates from RANKL ${ }^{-1-}$ mice as Class III to $\mathrm{V}$ based solely on their area points out the ability of these CPs to expand without attracting B cells.

\section{In Utero LT $\beta R$-Ig Treatment Fails to Restore ILF Development in RANKL ${ }^{-/}$Mice}

Because ILF development is dependent on the status of the commensal gut flora, most conventionally housed mice on a C57BL/6 background fail to develop large numbers of ILFs. ILF development in wild-type mice can be enhanced by in utero treatment with LT $\beta R$-Ig, which blocks formation of PPs leading to a compensatory increase in the number of ILFs. ${ }^{15,19}$ Pregnant RANKL $^{+/-}$ female mice that had been bred with $R A N K L^{-1-}$ male mice were treated with $L T \beta R$-Ig. The resultant $R A N K L^{-/-}$ and control $R A N K L^{+/-}$offspring lacked PPs, indicating the treatment successfully blocked PP development. Similar to previous studies, ${ }^{19}$ in utero LT $\beta$ R-Ig treatment of $R A N K L^{+1-}$ mice resulted in a threefold increase in the number of aggregates (Figure 3A). These aggregates included a high percentage of ILFs that had a greater average size than aggregates in untreated mice (Figure 3B). This increase skewed the distribution of lymphoid aggregates, with an increased number of Class IV to $\mathrm{VI}$ structures (Figure 3C). However, the RANKL ${ }^{-1-}$ mice showed no increase in the number of small intestinal 
A

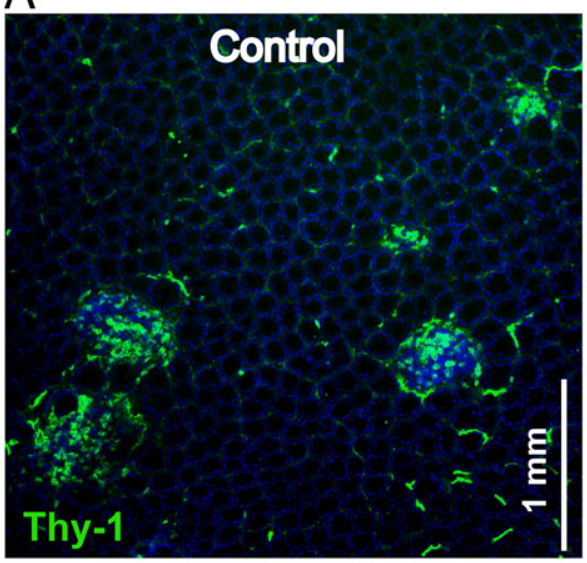

C

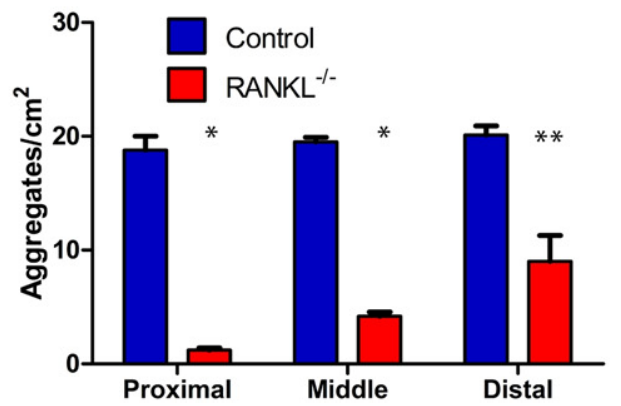

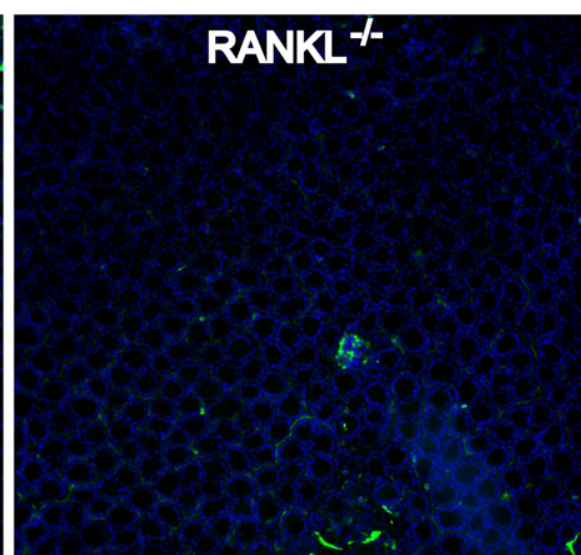

B

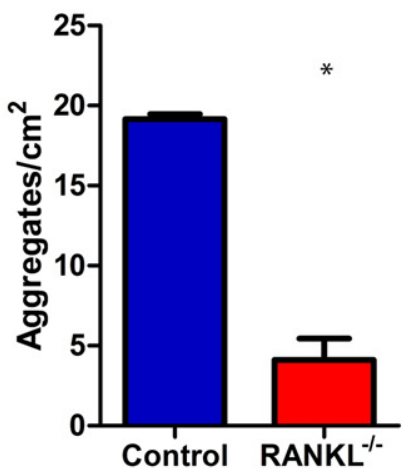

D

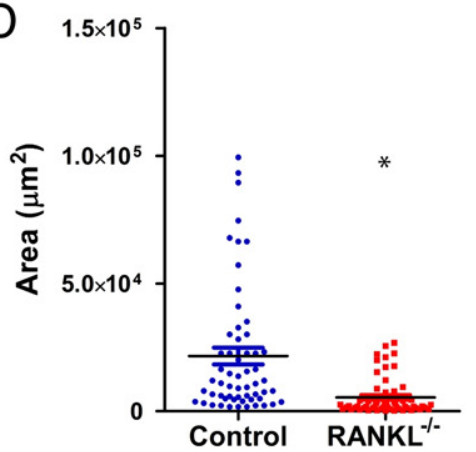

E

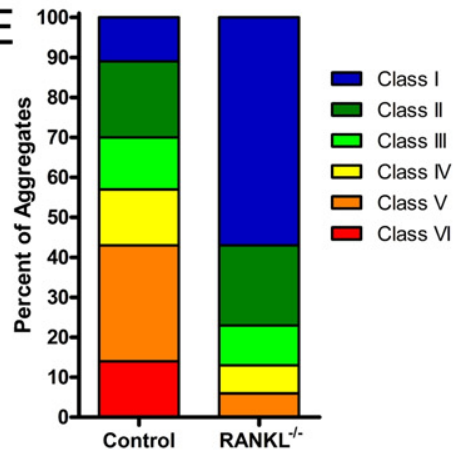

Figure 1. Cryptopatches are less frequent and smaller in the small intestine of $R A N K L^{-/-}$mice. A: Horizontal sections of the pericryptal lamina propria in the distal ileum from $R A N K L^{-1-}$ mice and littermate controls were stained with anti-Thy-1 and DAPI. Scale bar $=1 \mathrm{~mm}$. B: $R A N K L^{-1-}$ mice had a reduced density of small intestinal lymphoid aggregates. C: The reduction in the mean density of small intestinal lymphoid aggregates in $R A N K L^{-/-}$mice was greatest in the proximal small intestine (proximal $=0$ to $10 \mathrm{~cm}$; middle $=10$ to $20 \mathrm{~cm}$; distal = beyond $20 \mathrm{~cm}$ ). D: The average size of small intestinal lymphoid aggregates was reduced in $R A N K L^{-1-}$ mice. E: Divided bar graph depicting the size distribution of small intestinal lymphoid aggregates in $R A N K L^{-1-}$ and control mice by assigning them to one of six previously described classes based on their size. ${ }^{11}$ This analysis used three $R A N K L^{-1-}$ mice on a $\mathrm{C} 57 \mathrm{BL} / 6$ background and two $R A N K L^{-/-}$mice on an $\mathrm{F}_{1}$ equivalent background with a matched number of littermate controls. ${ }^{*} P \leq 0.001,{ }^{* * *} P \leq 0.01$ (compared to control mice by $t$-test).

lymphoid aggregates after in utero LT $\beta$ R-Ig treatment (Figure 3A). The aggregates present in the LT $\beta$ R-Igtreated $R A N K L^{-1-}$ mice were not increased in size compared to untreated $R A N K L^{-1-}$ mice (Figure 3, B and $\mathrm{C}$ ) and still lacked any B cells (data not shown).

\section{RANKL ${ }^{-\prime-}$ Mice Develop Colonic Aggregates That Include B-Cell Follicles}

Previous studies on CP and ILF development have largely focused on either the small intestine or the colon,
A

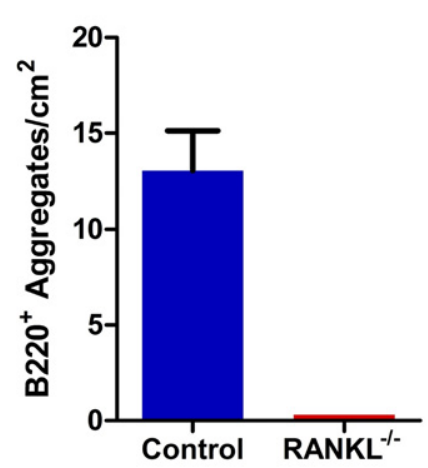

$\mathrm{B}$

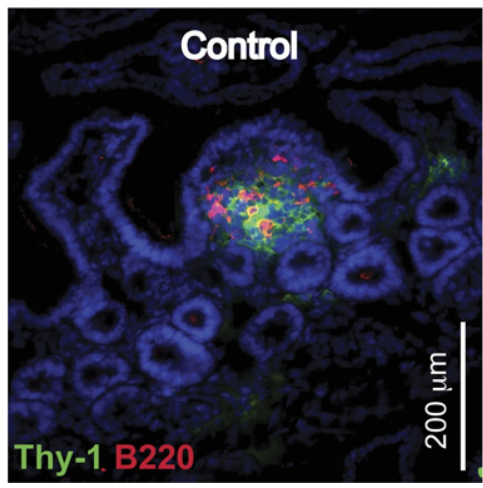

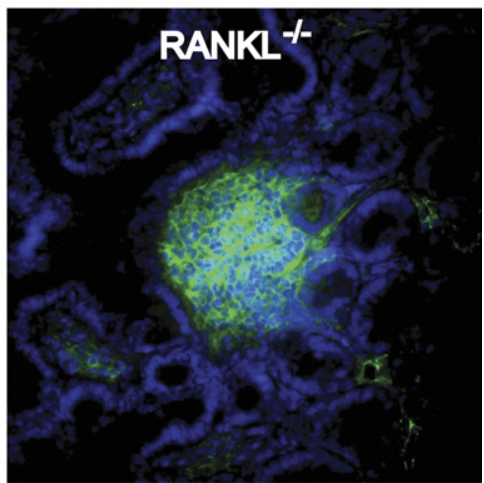

Figure 2. Cryptopatches in the small intestine of $R A N K L^{-/-}$mice do not contain any B cells. A: Density of lymphoid aggregates containing B220 ${ }^{+}$cells in the small intestine of $R A N K L^{-1-}$ and littermate control mice. B: Horizontal sections of the pericryptal lamina propria in the distal ileum were stained with anti-Thy-1, anti-B220, and DAPI. Representative images show that B220 ${ }^{+}$cells were absent in all of the $R A N K L^{-1-}$ lymphoid aggregates. Scale bar $=200 \mu \mathrm{m}$. This analysis used three $R A N K L^{-/-}$mice on a C57BL/6 background and two $R A N K L^{-/-}$mice on an $\mathrm{F}_{1}$ equivalent background with a matched number of littermate controls. 
A

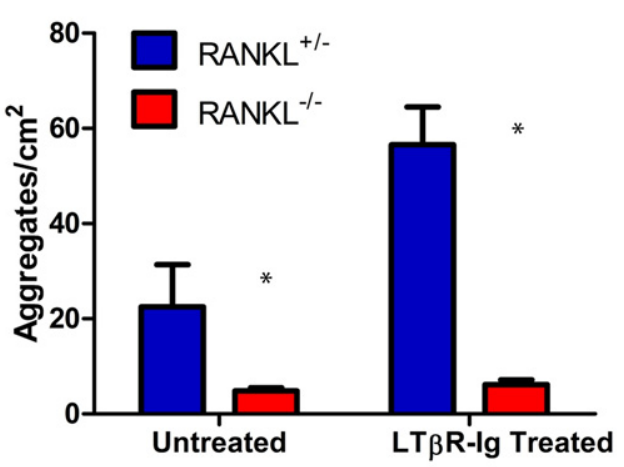

C

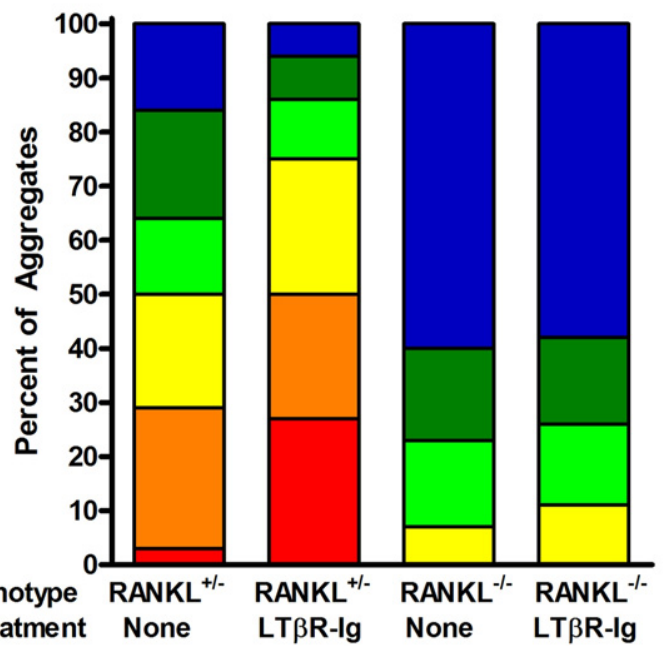

B

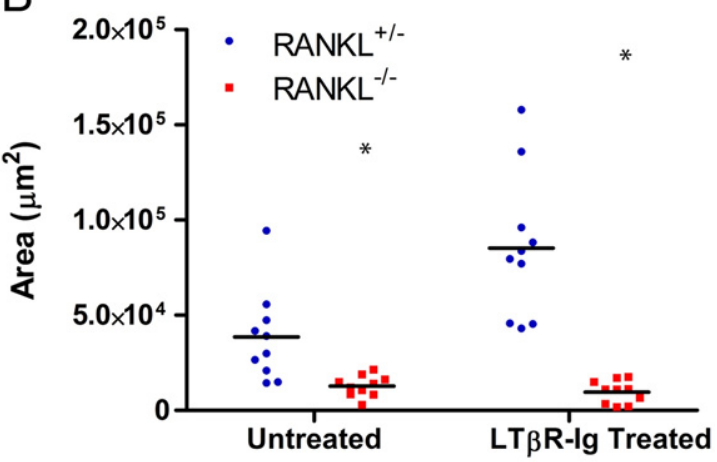

Class I

Class II

Class III

Class IV

Class V

Class VI isolated lymphoid follicle development in the small intestine of $R A N K L^{-1-}$ mice. In utero LT $\beta \mathrm{R}-\mathrm{Ig}$ treatment increased both the density (A) and average size of lymphoid aggregates $(\mathbf{B})$ in $R A N K L^{+/-}$mice, but the density and size of the aggregates were not increased in $R A N K L^{-/-}$mice. C: Divided bar graph depicting the size distribution of small intestinal lymphoid aggregates shows the shift to larger classes after LT $\beta$ R-Ig treatmen in $R A N K L^{+/-}$mice, but not $R A N K L^{-/-}$mice. This anal ysis used three mice of each genotype on a $\mathrm{C} 57 \mathrm{BL} / 6$ background. ${ }^{*} P \leq 0.001$ (compared to $R A N K L^{+/-}$mice by analysis of variance). rather than comparing formation of these lymphoid aggregates in both tissues. We investigated whether the defects in CP and ILF development found in the small intestine of $R A N K^{-1-}$ mice were also present in the colon. The colonic lamina propria in $R A N K L^{-1-}$ and littermate control mice had a similar density of Thy $-1^{+}$clusters (Figure 4, A and B). On average RANKL ${ }^{-1-}$ colonic aggregates were roughly one third of the size of control colonic aggregates, with an average area of 27,954 $\mu \mathrm{m}^{2}$ compared to $84,160 \mu \mathrm{m}^{2}$, respectively. Assigning these aggregates to Classes I to VI using the SILT classification revealed that the smaller classes of aggregates (Class II to IV) were increased in frequency at the expense of the Class VI aggregates. Despite the smaller average size of colonic lymphoid aggregates in $R A N K L^{-1-}$ mice, these aggregates had a frequency of $\mathrm{B}^{2} 20^{+}$cells similar to colonic lymphoid aggregates in control mice (Figure 4C). The colonic ILFs in RANKL ${ }^{-1-}$ mice included some mature ILFs covered by a FAE, demonstrating that the full spectrum of ILF development can be completed in the colon in the absence of RANKL. However, M cells, as identified by their expression of the M cell-specific marker GP2, ${ }^{20}$ were present in the FAE overlaying colonic ILFs in RANKL ${ }^{+/-}$mice, but not in $R A N K L^{-1-}$ mice (Figure 4D). We previously showed that differentiation of $M$ cells in the PP FAE requires $R A N K L{ }^{18}$

\section{The Density and Distribution of $\mathrm{CD} 11 \mathrm{C}^{+}$Cells Are Not Perturbed in $\mathrm{RANKL}^{-1-} \mathrm{CP}$}

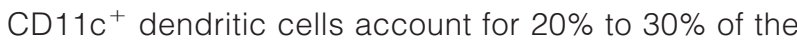
cells in the small intestinal CP of adult mice. ${ }^{7}$ These $\mathrm{CD}_{11 \mathrm{C}^{+}}$cells are concentrated at the border of CPS, with the Thy- $1^{+}$LTi cells predominating centrally. ${ }^{7,21}$ During the postnatal development of $\mathrm{CP}$, clusters of CD $11 \mathrm{C}^{+}$cells associate with CP before the influx of $\mathrm{B}$ cells to generate ILF begins. ${ }^{22}$ We examined the distribution of $\mathrm{CD} 11 \mathrm{c}^{+}$cells in $R A N K L^{-1-}$ CPs to ascertain whether a failure to recruit normal numbers of CD11 $\mathrm{c}^{+}$ cells or a perturbation in the distribution of $\mathrm{CD}_{11 \mathrm{C}^{+}}$ cells might be a contributor to the failure of $R A N K L^{-1-}$ CPs to progress to ILF development. CPs in adult $R A N K^{-1-}$ mice had a density and distribution of $\mathrm{CD}_{11 \mathrm{C}^{+}}$cells that was unchanged from CPs in control mice (Figure 5).

\section{CXCL13 Is Not Expressed within CPs in the Small Intestine of $\mathrm{RANKL}^{-/-}$Mice}

CXCL13 is a chemokine expressed by stromal cells in organized lymphoid structures, including CPS and ILFs, that plays a critical role in the recruitment of $\mathrm{B}$ cells. ${ }^{23}$ Intestinal tissue from $R A N K L^{-1-}$ mice and controls was stained with antibodies to CXCL13. In control mice, 

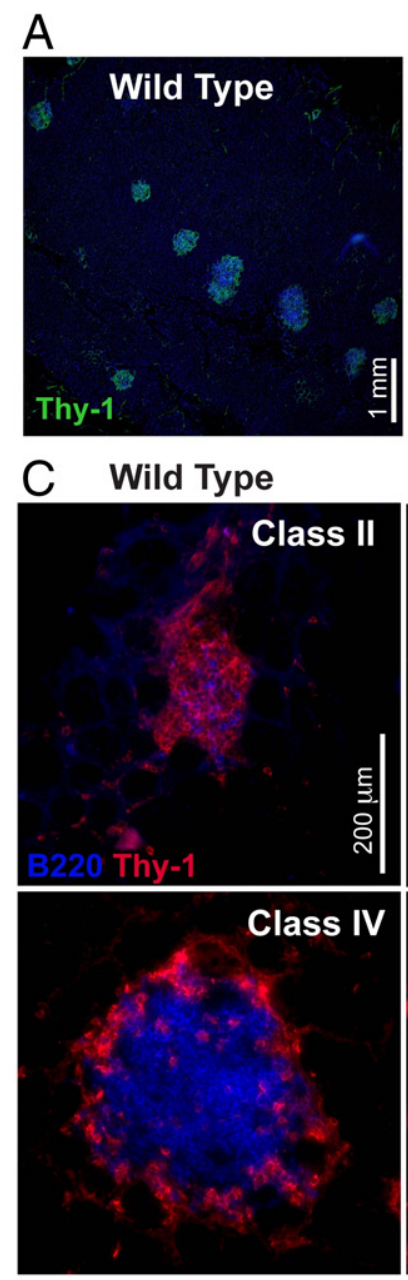

D Wild Type

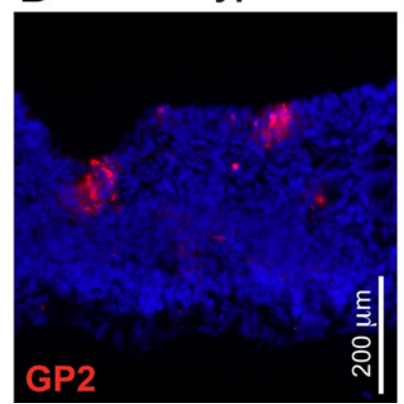

B

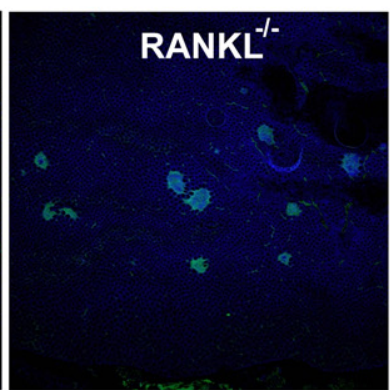

RANKL $^{-1-}$
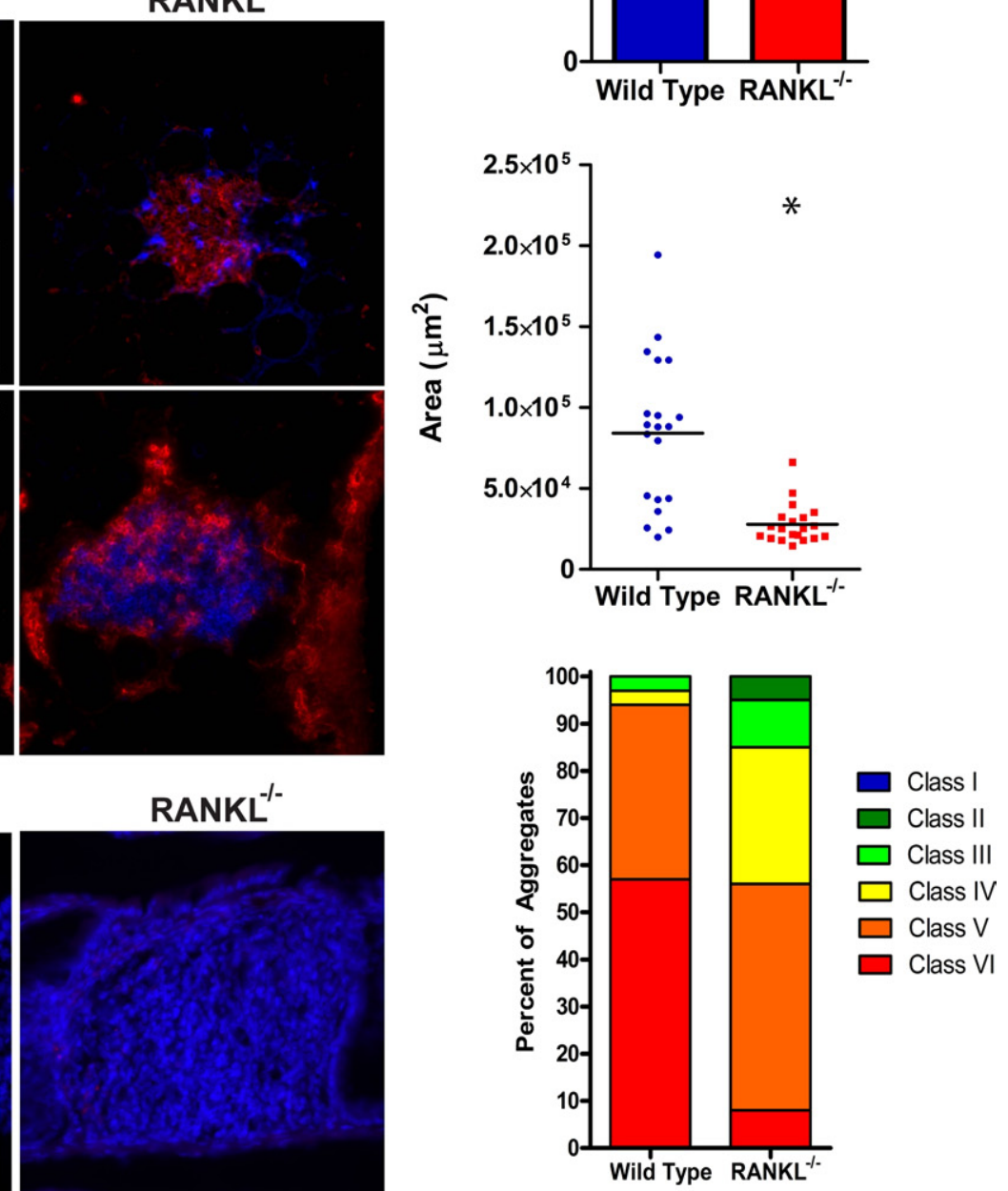

Figure 4. Colonic lymphoid aggregates in $R A N K L^{-/}$mice include B-cell follicles. A: Horizontal sections of colon were stained with anti-Thy-1 and DAPI revealing a similar density of lymphoid aggregates in $R A N K L^{-1-}$ and littermate control mice. Scale bar $=1 \mathrm{~mm}$. B: The density of colonic lymphoid aggregates in $R A N K L^{-/-}$mice was not significantly different from control mice, but the average size of the lymphoid aggregates was significantly reduced. C: Representative images of Class II and Class IV lymphoid aggregates show that follicles of B220 ${ }^{+}$cells were present in lymphoid aggregates of both $R A N K L^{-/-}$and control mice. Scale bar $=200 \mu \mathrm{m}$. This analysis used three $R A N K L^{-/-}$mice on a C57BL/6 background and two $R A N K L^{-/-}$mice on an $\mathrm{F}_{1}$ equivalent background with a matched number of littermate controls. ${ }^{*} P \leq 0.001$ (compared to control mice by $t$-test). D: Representative images of colonic ILF stained with anti-GP2 and DAPI show M cells are present in $R A N K L^{+/-}$, but not $R A N K L^{-/-}$FAE. Scale bar $=200 \mu \mathrm{m}$.

CXCL13 was found on stromal cells in all B-cell follicles in the gut, including both small intestinal and colonic aggregates (Figure 6). In RANKL ${ }^{-\prime-}$ mice, CXCL13 was not detected in $R A N K L^{-1-}$ small intestinal aggregates (Figure $6 \mathrm{~A}$ ), but remained present in the colonic lymphoid aggregates that contained B-cell-containing follicles (Figure 6B).
Stromal Cells in Small Intestinal CPs from RANKL ${ }^{-1-}$ Mice Fail to Express Several LT $\beta R$-Dependent Stromal Cell Antigens

We previously reported that all CPs in wild-type mice include stromal cells that express FDC-M1, VCAM-1, and CD157. ${ }^{15}$ Although all CPs in the RANKL ${ }^{-1-}$ small intes- 

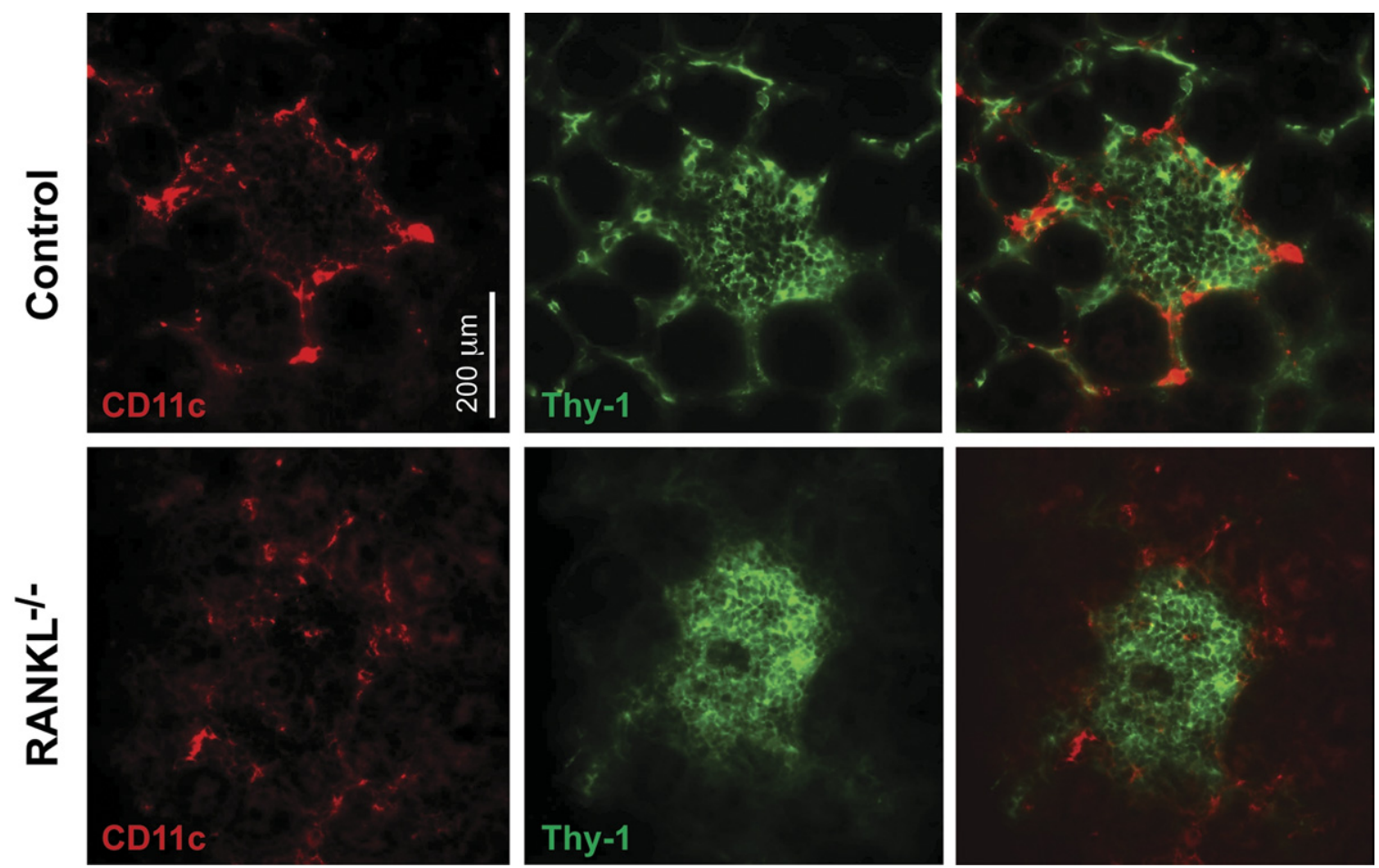

Figure 5. $R A N K L^{-/}$cryptopatches have a normal density and distribution of CD11c ${ }^{+}$cells. Cryptopatches in horizontal sections of small intestine from $R A N K L^{--}$and control small intestine were stained for Thy-1 and CD11c. The density and peripheral distribution of CD11c ${ }^{+}$cells were similar in $R A N K L^{-}$ cryptopatches and control cryptopatches. Scale bar $=200 \mu \mathrm{m}$. The representative images shown are from a $R A N K L^{-/}$mouse on an $\mathrm{F}_{1}$ equivalent background and a littermate control, but similar results were obtained with two $R A N K L^{-1-}$ mice and controls on a C57BL/6 background.

tine included FDC-M1 ${ }^{+}$stromal cells, most of these CPs did not include any stromal cells expressing VCAM-1 or CD157 (Figure 7A). None of the small intestinal CPs from RANKL ${ }^{-1-}$ mice examined had both VCAM- $1^{+}$and $\mathrm{CD}_{157^{+}}$stromal cells, the pattern found in all control CPs. In $84 \%$ of the CPs from RANKL ${ }^{-1-}$ mice, no stromal cell expression of VCAM-1 or CD157 was detected. In the other $16 \%$ of CPs, only CD $157^{+}$stromal cells were found. In contrast with the stromal cell abnormalities observed in small intestinal CPs from $R A N K L^{-1-}$ mice, colonic lymphoid aggregates from $R A N K L^{-1-}$ mice and control mice contained stromal cells expressing VCAM-1 and CD157 to the same extent as in small intestinal CPs and ILFs from control mice (Figure 7B). To determine whether the altered pattern of stromal cell antigen expression in the small intestinal CPs of RANKL ${ }^{-1-}$ mice could be corrected by providing an exogenous source of RANKL, $R A N K L^{-\prime-}$ mice were treated with $100 \mu \mathrm{g}$ of GST-RANKL for 5 days. Although this treatment was previously shown to be sufficient to restore $\mathrm{M}$ cell differentiation in the PPs of $R A N K L^{-1-}$ mice, ${ }^{18}$ it failed to normalize stromal cell antigen expression in the small intestinal CPs or bring about recruitment of $\mathrm{B}$ cells into the CPs (data not shown).

\section{Discussion}

The early stages of lymphoid tissue development involve exchange of a series of cytokine-mediated signals between LTi cells and lymphoid tissue organizer cells.
RANKL has a critical role in these interactions as evidenced by the complete absence of lymph nodes in RANKL-deficient mice. 2,3 Not all secondary lymphoid tissues fail to develop in the absence of RANKL. Intestinal PPs are present in $R A N K L^{-1-}$ mice, although they are smaller and exhibit a profound deficiency in the formation of $\mathrm{M}$ cells. ${ }^{18}$ The contribution of RANKL to the development of the organized lymphoid tissues of the intestine that develop postnatally (ie, CPs and ILFs) has not been previously examined.

The absence of RANKL results in multiple abnormalities in CP and ILF development in the small intestine, but does not compromise development of these structures in the colon. Small intestinal CPs from $R A N K L^{-\prime-}$ mice are both fewer in number and smaller compared to CPs from wild-type mice. Furthermore, the CPs that remain in the small intestine of $R A N K L^{-1-}$ mice do not include any $B$ cells, and no ILFs form in the small intestine. Even when in utero $\mathrm{LT} \beta \mathrm{R}$-Ig treatment was used as a stimulus to enhance the extent of postnatal ILF development, no small intestinal ILF development was observed in $R A N K L^{-\prime-}$ mice. In contrast, colonic CPs from $R A N K L^{-/-}$ mice were present at a normal density and are capable of maturing into ILFs. The development of colonic ILFs, but not small intestinal ILFs, in $R A N K L^{-1-}$ mice demonstrates that ILF development is differentially regulated in the small intestine and colon.

The most striking feature of the $R A N K^{-1-}$ small intestinal CPs was the complete absence of any B-cell clusters within these CPs. Our results indicate that loss of 
A
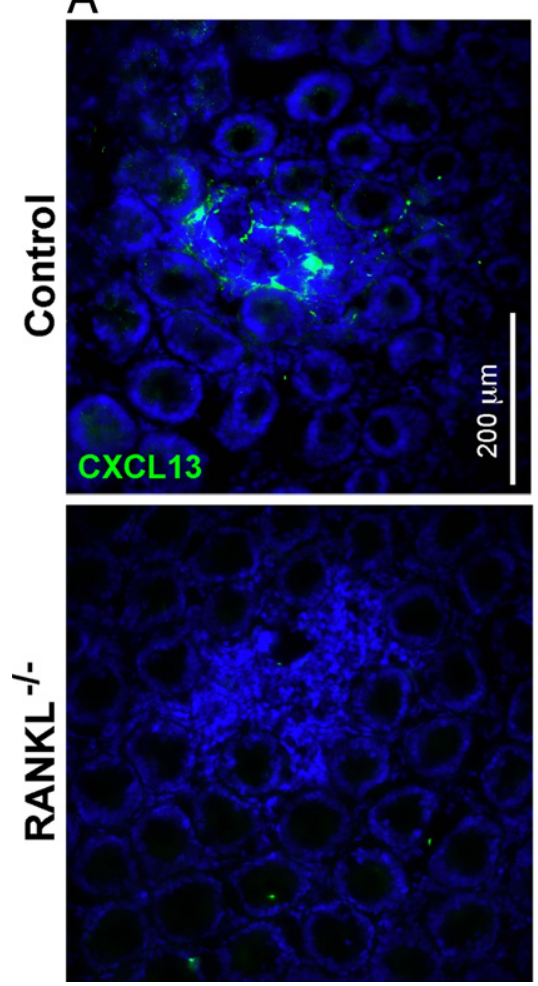
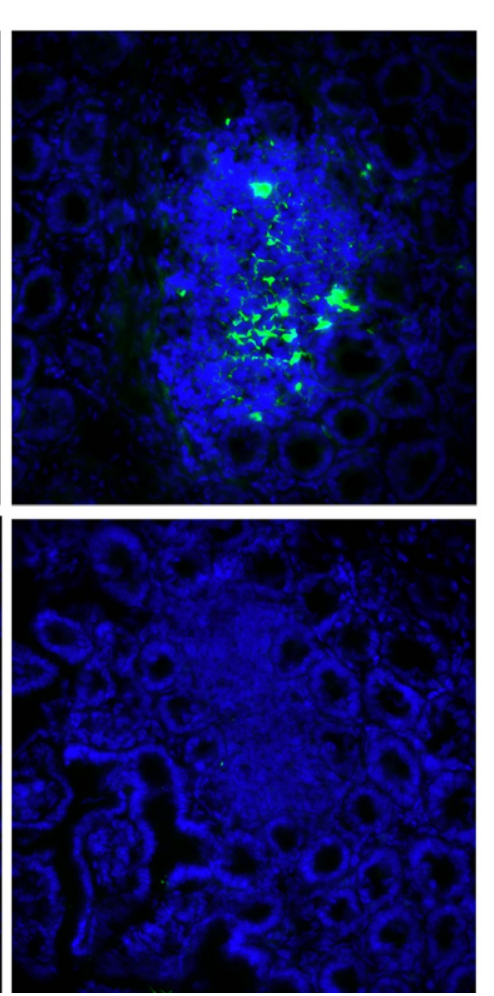

B
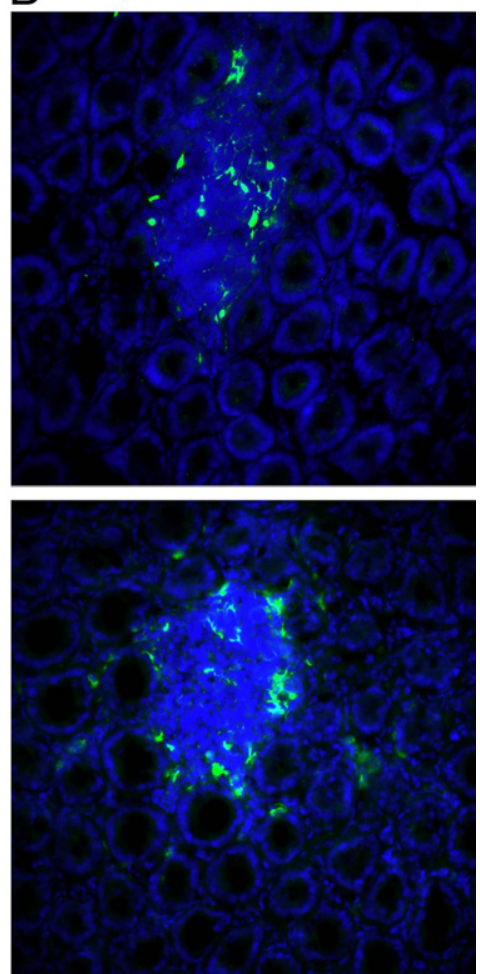

Figure 6. CXCL13-expressing cells are absent from small intestinal lymphoid aggregates in $R A N K L^{-/-}$mice. Horizontal sections of small intestine (A) and colon (B) were stained for CXCL13 expression. Representative images demonstrate that CXCL13-expressing cells were only detected in the colon of $R A N K L^{-/-}$mice. Scale bar $=200 \mu \mathrm{m}$. This analysis used three $R A N K L^{-/-}$mice on an $\mathrm{F}_{1}$ equivalent background and three littermate controls.

CXCL13 expression in the stroma of the CPs may be a pivotal factor in the inability of these structures to recruit and incorporate B cells, allowing maturation into ILFs. CXCL13 has been identified as an important factor in the initiation of lymphoid tissue development by virtue of its ability to attract LTi cells to sites of lymphoid organogenesis. ${ }^{24-26}$ In embryonic lymph node development, stimulation of neurons elicits retinoic acid production leading to CXCL13 expression by lymph node organizer cells, thus triggering the initial formation of the lymph node anlagen without a requirement for $\mathrm{LT}-\alpha .{ }^{27} \mathrm{CXCL} 13$ also contributes to the formation of B-cell follicles in nasopharynx-associated lymphoid tissue and omental milky spots. ${ }^{28,29}$ Intestinal CPS and ILFs also depend on CXCL13 for B-cell recruitment and maturation into ILFS. CXCL13 $13^{-1-}$ mice have normal numbers of CPs, but lack $\mathrm{B} 220^{+}$ILFs, thus showing the dependence on CXCL13 for the accumulation and organization of $B$ cells, but not the initial development of CPs. ${ }^{22}$ Knocking out the CXCR5 receptor for CXCL13 results in a similar pheno-

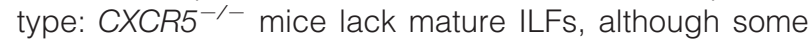
aggregates still have a limited number of B cells. ${ }^{8}$ Increasing the local concentration of CXCL13 through transgenic expression by gut epithelial cells results in an increase in B-cell accumulation and ILF development in the jejunum and ileum. ${ }^{30}$ Although the overexpression of CXCL13 in these mice also increased the number of $\mathrm{ROR} \gamma \mathrm{t}^{+} \mathrm{LTi}$ cells, there was no increase in the absolute number of intestinal aggregates. The conspicuous absence of $\mathrm{CXCL13}$ in small intestinal aggregates in
$\mathrm{RANKL}^{-1-}$ mice reveals that expression of CXCL13 by stromal cells in small intestinal CPs is dependent on RANKL. This dependency does not extend to colonic lymphoid aggregates from the $R A N K L^{-1-}$ mice, since CXCL13 expression is maintained and ILFs still develop.

The requirement for RANKL to achieve CXCL13 expression in small intestinal CPs may be a consequence of RANKL's demonstrated ability to promote LT $\alpha_{1} \beta_{2}$ expression. During the fetal development of lymph nodes, RANKL is not required for the earliest steps in lymph node development. Instead, RANKL participates in a positive feedback loop involving $L T \alpha_{1} \beta_{2}$ that is required for lymph node development to continue. ${ }^{31} \mathrm{CP}$ development is thought to closely resemble fetal lymph node development in many respects, and CPs also contain ROR $\gamma \mathrm{t}^{+} \mathrm{LTi}_{\text {cells. }}{ }^{32,33} \mathrm{RANKL}$ is also not required for the initial step in CP development, as $R A N K L^{-1-}$ mice still have some CPs, although the reduced number of CPs in $R A N K L^{-1-}$ mice reveals RANKL is an important factor in achieving full CP development. Growth of developing CPs relies on the continued cross talk between LTi cells, which express RANK, RANKL and CXCR5, and VCAM $-1^{+}$organizer cells that express RANKL and CXCL13 upon LT $\beta$ R signaling. ${ }^{34,35}$ Decreased $\mathrm{LT} \alpha_{1} \beta_{2}$ expression caused by absence of RANKL may lead to loss of CXCL13 expression, which in turn inhibits further CP development and prevents their maturation into ILFs.

Our results also show the small intestinal CPs that develop in $R A N K L^{-1-}$ mice fail to express stromal antigens such as VCAM-1 and CD157 that are normally pres- 
A

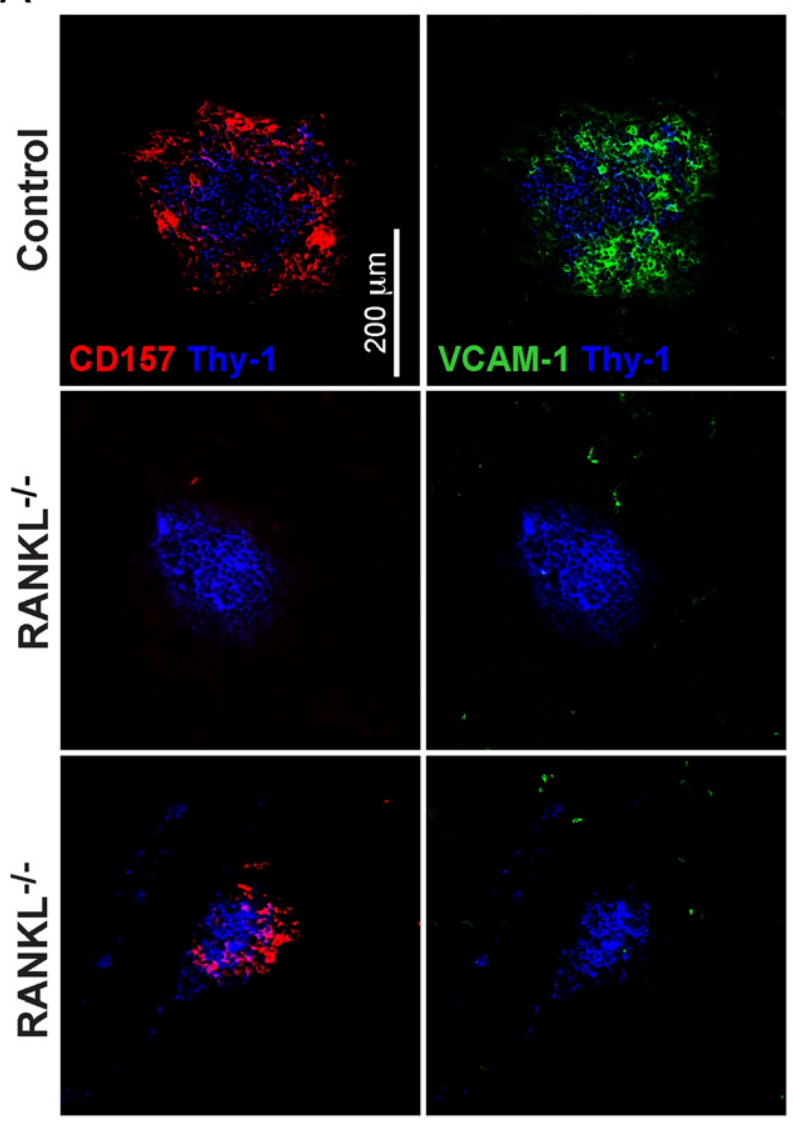

B

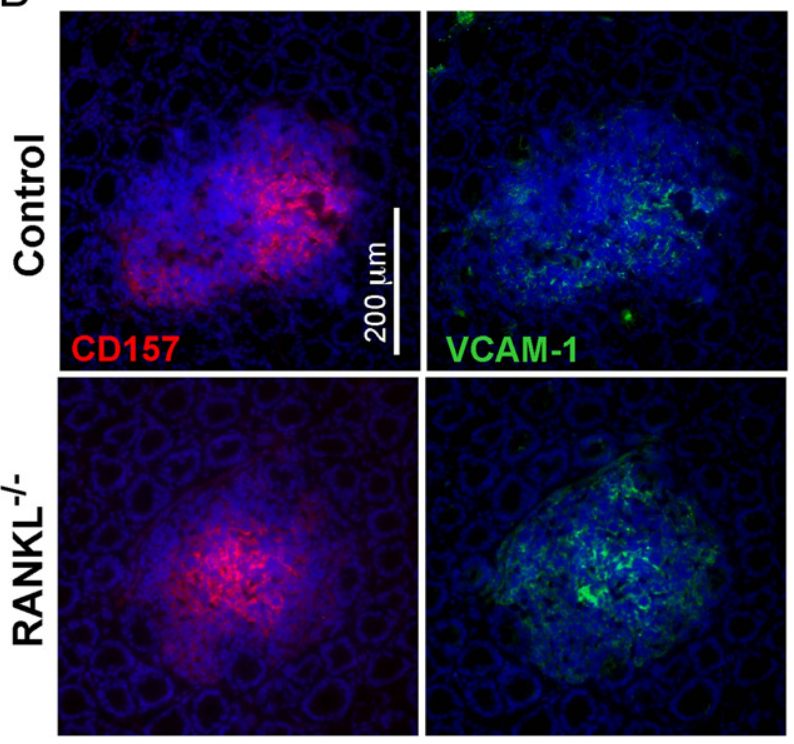

Figure 7. Stromal cells in small intestinal but not colonic cryptopatches from $R A N K L^{-/-}$mice do not express several LT $\beta$ R-dependent antigens. A: Horizontal sections of small intestine stained for VCAM-1 and CD157 revealed that most $R A N K L^{-/-}$cryptopatches lack expression of both of these antigens found on stromal cells in all cryptopatches in littermate control mice. Scale bar $=200 \mu \mathrm{m}$. B: Horizontal sections of colon stained with anti-VCAM-1, anti-CD157, and DAPI showed all aggregates in $R A N K L^{-/-}$mice and control mice included both VCAM- ${ }^{+}$and $\mathrm{CD} 157^{+}$stromal cells. Scale bar $=200 \mu \mathrm{m}$. The representative images shown are from two $R A N K L^{-/-}$mice on an $\mathrm{F}_{1}$ equivalent background and two littermate controls. ent on the stroma of CPs in wild-type mice. ${ }^{15}$ In previous studies, we showed that aly/aly mice lacking functional $\mathrm{NF}-\kappa \mathrm{B}$-inducing kinase (NIK) or wild-type mice in which $\mathrm{LT} \alpha_{1} \beta_{2}$ signaling was blocked with $\mathrm{LT} \beta \mathrm{R}$-lg also had defective stromal antigen expression in CPs, failing to express VCAM-1, CD157, and FDC-M1, but retaining RANKL expression. The CPs from the aly/aly mice also failed to develop into ILFs. In aggregate, these findings point to a requirement in the small intestine for multiple factors, including RANKL and $\mathrm{LT} \alpha_{1} \beta_{2}$, for normal stromal cell differentiation in CPS and the development of ILFs from these CPs.

A major difference between the small intestine and the colon is the increase in the density of the commensal flora in the colon. Although signals derived from the enteric microflora are not required for CP development, commensal bacteria influence the size of CPs, because germ-free wild-type mice were found to have smaller CPs. ${ }^{14}$ Sensing of the enteric microflora by nucleotidebinding oligomerization domain protein 1 (NOD1) was identified as a critical signal driving the differentiation of CPs into immature ILFs. ${ }^{36}$ Although RANKL $^{-1-}$ mice are normally colonized by gut commensals, we previously showed they have less than $2 \%$ of the normal number of antigen-sampling $\mathrm{M}$ cells compared to wild-type mice. ${ }^{18}$ This profound $\mathrm{M}$ cell deficit in $R A N K L^{-1-}$ mice likely results in decreased antigen-sampling of the commensal flora, thereby impairing the NOD1-initiated differentiation of CPs into immature ILFs. Follicular dendritic cells isolated from PP have the capacity to respond directly to environmental stimuli, including retinoic acid and intestinal bacteria, by increasing production of both CXCL13 and BAFF, ${ }^{37}$ indicating that stromal cells are able to directly sense the presence of the commensal enteric flora. In wild-type mice, the density of CPs is relatively uniform in different portions of the small intestine despite a gradient in the density of the enteric microflora between the proximal and distal end. The increase in the density of CPs in the distal small intestine of $\mathrm{RANKL}^{-/-}$mice compared to the proximal small intestine parallels the increase in the density of the commensal flora. The proximal-to-distal gradient of CP density in the small intestine of $\mathrm{RANKL}^{-1-}$ mice and the lack of stromal CXCL13 expression suggest that the density of the commensal flora has the potential to influence the extent of CP development in the small intestine, but this effect is normally overridden by the contribution of other signals. In the colon, the density of the commensal flora may be high enough that direct induction of CXCL13 expression on stromal cells in lymphoid aggregates is sufficient to override the requirement for RANKL evident in the small intestine. The contribution of RANKL to colonic lymphoid aggregate development is limited to influencing the extent of B-cell recruitment and the final size attained by ILFs.

In summary, we have shown that the development of ILFs from precursor CPs in the small intestine is dependent on RANKL for the expression of CXCL13. Surprisingly, this requirement for RANKL for induction of CXCL13 and ILF development did not extend to colonic lymphoid aggregates. The differential dependence on 
RANKL for development of lymphoid structures in the small intestine and colon suggests that other molecules involved in CP and ILF development may also be differentially used between these tissues. Previous studies have revealed that the status of the commensal enteric flora exerts a far greater influence on the number of ILFS that develop in the small intestine compared to the coIon. ${ }^{38}$ Our findings reveal a new role for RANKL in CP and ILF formation in the small intestine and also provide new evidence that the molecular pathways that contribute to the initiation and maturation of these lymphoid aggregates are not identical in the small intestine and colon.

\section{References}

1. Mebius RE: Organogenesis of Iymphoid tissues. Nat Rev Immunol 2003, 3:292-303

2. Kong YY, Yoshida H, Sarosi I, Tan HL, Timms E, Capparelli C, Morony S, Oliveira-dos-Santos AJ, Van G, Itie A, Khoo W, Wakeham A, Dunstan CR, Lacey DL, Mak TW, Boyle WJ, Penninger JM: OPGL is a key regulator of osteoclastogenesis, lymphocyte development and lymph-node organogenesis. Nature 1999, 397:315-323

3. Yoshida H, Naito A, Inoue J, Satoh M, Santee-Cooper SM, Ware CF Togawa A, Nishikawa S: Different cytokines induce surface lymphotoxin- $\alpha \beta$ on IL-7 receptor- $\alpha$ cells that differentially engender lymph nodes and Peyer's patches. Immunity 2002, 17:823-833

4. Ruddle NH, Akirav EM: Secondary lymphoid organs: responding to genetic and environmental cues in ontogeny and the immune response. J Immunol 2009, 183:2205-2212

5. Roozendaal R, Mebius RE: Stromal cell-immune cell interactions. Annu Rev Immunol 2011, 29:23-43

6. Taylor RT, Williams IR: Lymphoid organogenesis in the intestine. Immunol Res 2005, 33:167-182

7. Kanamori $Y$, Ishimaru K, Nanno M, Maki K, Ikuta K, Nariuchi H, Ishikawa $\mathrm{H}$ : Identification of novel lymphoid tissues in murine intestinal mucosa where clusters of ${\mathrm{c}-\mathrm{kit}^{+}}^{+} \mathrm{IL}-7 \mathrm{R}^{+}$Thy $1^{+}$Iympho-hemopoietic progenitors develop. J Exp Med 1996, 184:1449-1459

8. Velaga S, Herbrand H, Friedrichsen M, Jiong T, Dorsch M, Hoffmann MW, Forster R, Pabst O: Chemokine receptor CXCR5 supports solitary intestinal lymphoid tissue formation. B cell homing, and induction of intestinal IgA responses, J Immunol 2009, 182:2610-2619

9. Hamada $H$, Hiroi $T$, Nishiyama $Y$, Takahashi $H$, Masunaga $Y$, Hachimura S, Kaminogawa S, Takahashi-Iwanaga $H$, Iwanaga $T$, Kiyono $\mathrm{H}$, Yamamoto $\mathrm{H}$, Ishikawa $\mathrm{H}$ : Identification of multiple isolated lymphoid follicles on the antimesenteric wall of the mouse small intestine. J Immunol 2002, 168:57-64

10. Lorenz RG, Newberry RD: Isolated lymphoid follicles can function as sites for induction of mucosal immune responses. Ann N Y Acad Sci 2004, 1029:44-57

11. Pabst $\mathrm{O}$, Herbrand $\mathrm{H}$, Worbs T, Friedrichsen M, Yan S, Hoffmann MW, Korner H, Bernhardt G, Pabst R, Forster R: Cryptopatches and isolated lymphoid follicles: dynamic lymphoid tissues dispensable for the generation of intraepithelial Iymphocytes. Eur J Immunol 2005 35:98-107

12. Fagarasan $S$, Muramatsu $M$, Suzuki $K$, Nagaoka $H$, Hiai $H$, Honjo $T$ : Critical roles of activation-induced cytidine deaminase in the homeostasis of gut flora. Science 2002, 298:1424-1427

13. Lorenz RG, Chaplin DD, McDonald KG, McDonough JS, Newberry $\mathrm{RD}$ : Isolated lymphoid follicle formation is inducible and dependent upon lymphotoxin-sufficient $B$ lymphocytes, Iymphotoxin $\beta$ receptor, and TNF receptor I function. J Immunol 2003, 170:5475-5482

14. Pabst $\mathrm{O}$, Herbrand $H$, Friedrichsen $M$, Velaga S, Dorsch $M$, Berhardt G, Worbs T, Macpherson AJ, Forster R: Adaptation of solitary intestinal lymphoid tissue in response to microbiota and chemokine receptor CCR7 signaling. J Immunol 2006, 177:6824-6832

15. Taylor RT, Patel SR, Lin E, Butler BR, Lake JG, Newberry RD, Williams IR: Lymphotoxin-independent expression of TNF-related activationinduced cytokine by stromal cells in cryptopatches, isolated lymphoid follicles, and Peyer's patches. J Immunol 2007, 178:5659-5667
16. Kim D, Mebius RE, MacMicking JD, Jung S, Cupedo T, Castellanos Y, Rho J, Wong BR, Josien R, Kim N, Rennert PD, Choi Y: Regulation of peripheral lymph node genesis by the tumor necrosis factor family member TRANCE. J Exp Med 2000, 192:1467-1478

17. Dauner JG, Chappell CP, Williams IR, Jacob J: Perfusion fixation preserves enhanced yellow fluorescent protein and other cellular markers in lymphoid tissues. J Immunol Methods 2009, 340:116-122

18. Knoop KA, Kumar N, Butler BR, Sakthivel SK, Taylor RT, Nochi T, Akiba $H$, Yagita $H$, Kiyono $H$, Williams IR: RANKL is necessary and sufficient to initiate development of antigen-sampling $\mathrm{M}$ cells in the intestinal epithelium. J Immunol 2009, 183:5738-5747

19. Newberry RD, McDonough JS, McDonald KG, Lorenz RG: Postgestational lymphotoxin/lymphotoxin $\beta$ receptor interactions are essential for the presence of intestinal B lymphocytes. J Immunol 2002, 168: 4988-4997

20. Hase K, Kawano K, Nochi T, Pontes GS, Fukuda S, Ebisawa M, Kadokura K, Tobe T, Fujimura Y, Kawano S, Yabashi A, Waguri S, Nakato G, Kimura S, Murakami T, limura M, Hamura K, Fukuoka S, Lowe AW, Itoh K, Kiyono $\mathrm{H}$, Ohno $\mathrm{H}$ : Uptake through glycoprotein 2 of $\mathrm{FimH}^{+}$bacteria by $\mathrm{M}$ cells initiates mucosal immune response. Nature 2009, 462:226-230

21. Lügering A, Kucharzik T, Soler D, Picarella D, Hudson JT 3rd, Williams IR: Lymphoid precursors in intestinal cryptopatches express CCR6 and undergo dysregulated development in the absence of CCR6. J Immunol 2003, 171:2208-2215

22. McDonald KG, McDonough JS, Dieckgraefe BK, Newberry RD: Dendritic cells produce CXCL13 and participate in the development of murine small intestine lymphoid tissues. Am J Pathol 2010, 176:2367-2377

23. Ohl L, Henning G, Krautwald S, Lipp M, Hardtke S, Bernhardt G, Pabst O, Forster R: Cooperating mechanisms of CXCR5 and CCR7 in development and organization of secondary lymphoid organs. J Exp Med 2003, 197:1199-1204

24. Honda K, Nakano H, Yoshida H, Nishikawa S, Rennert P, Ikuta K, Tamechika M, Yamaguchi K, Fukumoto T, Chiba T, Nishikawa SI: Molecular basis for hematopoietic/mesenchymal interaction during initiation of Peyer's patch organogenesis. J Exp Med 2001, 193:621-630

25. Finke D, Acha-Orbea H, Mattis A, Lipp M, Kraehenbuhl J: CD4 ${ }^{+} \mathrm{CD} 3^{-}$ cells induce Peyer's patch development: role of $\alpha 4 \beta 1$ integrin activation by CXCR5. Immunity 2002, 17:363-373

26. Luther SA, Ansel KM, Cyster JG: Overlapping roles of CXCL13, interleukin 7 receptor $\alpha$, and CCR7 ligands in lymph node development. J Exp Med 2003, 197:1191-1198

27. van de Pavert SA, Olivier BJ, Goverse G, Vondenhoff MF, Greuter M, Beke P, Kusser K, Hopken UE, Lipp M, Niederreither K, Blomhoff R, Sitnik K, Agace WW, Randall TD, de Jonge WJ, Mebius RE: Chemokine CXCL13 is essential for lymph node initiation and is induced by retinoic acid and neuronal stimulation. Nat Immunol 2009, 10:11931199

28. Rangel-Moreno J, Moyron-Quiroz J, Kusser K, Hartson L, Nakano H, Randall TD: Role of CXC chemokine ligand 13, CC chemokine ligand (CCL) 19, and CCL21 in the organization and function of nasalassociated Iymphoid tissue. J Immunol 2005, 175: 4904-4913

29. Rangel-Moreno J, Moyron-Quiroz JE, Carragher DM, Kusser K, Hartson L, Moquin A, Randall TD: Omental milky spots develop in the absence of lymphoid tissue-inducer cells and support B and T cell responses to peritoneal antigens. Immunity 2009, 30:731-743

30. Marchesi F, Martin AP, Thirunarayanan N, Devany E, Mayer L, Grisotto MG, Furtado GC, Lira SA: CXCL13 expression in the gut promotes accumulation of IL-22-producing lymphoid tissue-inducer cells, and formation of isolated lymphoid follicles. Mucosal Immunol 2009, 2:486-494

31. Vondenhoff MF, Greuter M, Goverse G, Elewaut D, Dewint P, Ware CF, Hoorweg K, Kraal G, Mebius RE: LT $\beta$ R signaling induces cytokine expression and up-regulates lymphangiogenic factors in lymph node anlagen. J Immunol 2009, 182:5439-5445

32. Eberl G, Marmon S, Sunshine MJ, Rennert PD, Choi Y, Littman DR: An essential function for the nuclear receptor ROR $\gamma \mathrm{t}$ in the generation of fetal lymphoid tissue inducer cells. Nat Immunol 2004, 5:64-73

33. Eberl G: Inducible lymphoid tissues in the adult gut: recapitulation of a fetal developmental pathway?. Nat Rev Immunol 2005, 5:413-420

34. Katakai $T$, Suto $H$, Sugai $M$, Gonda $H$, Togawa A, Suematsu $S$, Ebisuno Y, Katagiri K, Kinashi T, Shimizu A: Organizer-like reticular stromal cell layer common to adult secondary lymphoid organs. $\mathrm{J}$ Immunol 2008, 181:6189-6200 
RANKL and Intestinal ILF Development 1871 AJP October 2011, Vol. 179, No. 4

35. Suto H, Katakai T, Sugai M, Kinashi T, Shimizu A: CXCL13 production by an established lymph node stromal cell line via lymphotoxin- $\beta$ receptor engagement involves the cooperation of multiple signaling pathways. Int Immunol 2009, 21:467-476

36. Bouskra D, Brezillon C, Berard M, Werts C, Varona R, Boneca IG, Eberl G: Lymphoid tissue genesis induced by commensals through NOD1 regulates intestinal homeostasis. Nature 2008, 456:507-510
37. Suzuki K, Kawamoto S, Maruya M, Fagarasan S: GALT: organization and dynamics leading to IgA synthesis. Adv Immunol 2010, 107:153-185

38. Kweon MN, Yamamoto M, Rennert PD, Park EJ, Lee AY, Chang SY, Hiroi T, Nanno M, Kiyono $\mathrm{H}$ : Prenatal blockage of lymphotoxin $\beta$ receptor and TNF receptor p55 signaling cascade resulted in the acceleration of tissue genesis for isolated lymphoid follicles in the large intestine. J Immunol 2005, 174:4365-4372 